NIKOLINA ADAMOVIĆ,

Belgrade City Museum

Belgrade, Serbia

nikolina.adamovic@mgb.org.rs

NATAŠA POPOVSKA,

Belgrade City Museum

Belgrade, Serbia
UDC: 371.383:902/904(497.11)"200/201";

069.12:902/904(497.11)"200/201”

Original research article

Received: February, $28^{\text {th }} 2013$

Accepted: October $15^{\text {th }} 2013$

\title{
CREATIVE WORKSHOPS FOR CHILDREN INSPIRED BY ARCHAEOLOGICAL EXHIBITIONS IN BELGRADE CITY MUSEUM
}

\begin{abstract}
In Belgrade City Museum, there were many activities whose overall objective is to popularize the Museum among children who are regarded as the primary target group for these planned activities. Many creative workshops for children were implemented during the last five years, and some of them were inspired by the various archaeological exhibitions which took place at the Museum. Children's workshops consisted of creative work and also had an educational content.

During the first archaeological exhibition, a workshop was organized for children with the concept Life in Clay (exhibition of Neolithic figurines). Children modeled figurines of clay, as Neolithic shapes. The next exhibitions were titled First toast (presentation of cups from Baden period) and Vinča, Fragments for Reconstruction of the Past (exhibition of various objects of Vinča period). Objects similar to those presented in the exhibitions were also modeled in clay by the children attending the Workshop. Workshop connected with a next archaeological exibition Painted ceramics (period from 15 th to 18th century) was much more complex. The children who attended this Workshop made plates and bowls using a pottery wheel and then decorated them by a specific painting technique. The last archaeological exhibition in the Belgrade City Museum was named Recte Illuminas (presentation of Roman ceramic lamps). Children painted clay copies of lamps and made candlesticks.

As a result of producing finished products, from the last two workshops, there stemmed the idea for an Exhibition and Sale of the children's finished work, which proved very constructive and intelectually rewarding for all participants.
\end{abstract}

Keywords: archaeological exhibitions, Belgrade City Museum, ceramics, Children’s Club, education, workshops.

The overall objective through the creative educational activities covered in the Workshops, was and is, to heighten a positive awareness for their history, heritage and culture among the children, who are regarded as the primary target group. As a result it is expected to support the popularization of science and the Museum among the younger generation.

The Workshops were located in the authentic ambience of Princess Ljubica's house in 


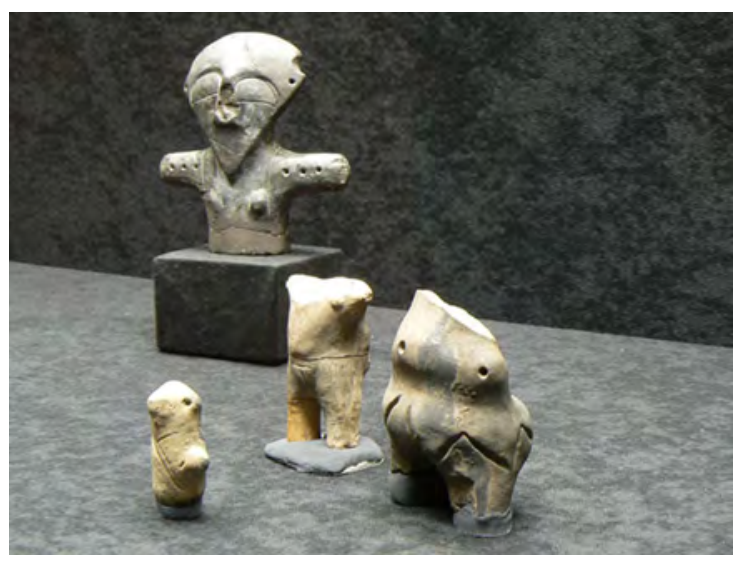

Fig. 1 Exhibition Life in Clay

Belgrade, where archeological exhibitions were located at the same venue. Like many museums in Serbia, Belgrade City Museum has limited financial resources and there is no specialized department for education within the Museum, consequently more simple economical solutions were found. All the programs were organized and realized by archaeologists and art historians employed by the Museum

In each planned Exhibition over the past five years, there were many creative hands-on workshops implemented for children. Some of these were inspired by the various archaeological exhibitions which took place at the Museum. Children's workshops consisted of creative work and also had an educational content and benefit aimed specifically at them as the target group. In parallel, children participating in the creative work gained some knowledge in a relaxed atmosphere encouraged by the curators and educators, who managed to achieve the three basic principles

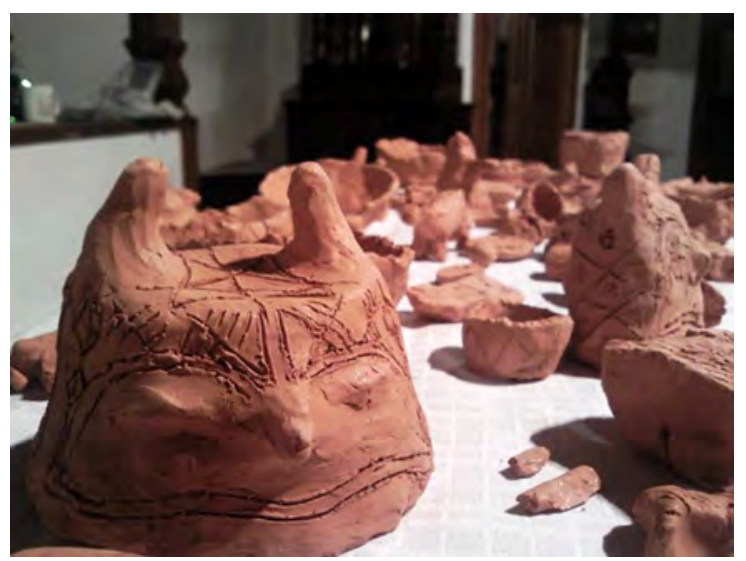

Fig. 3 Children's finished work: prosopomorphic lid

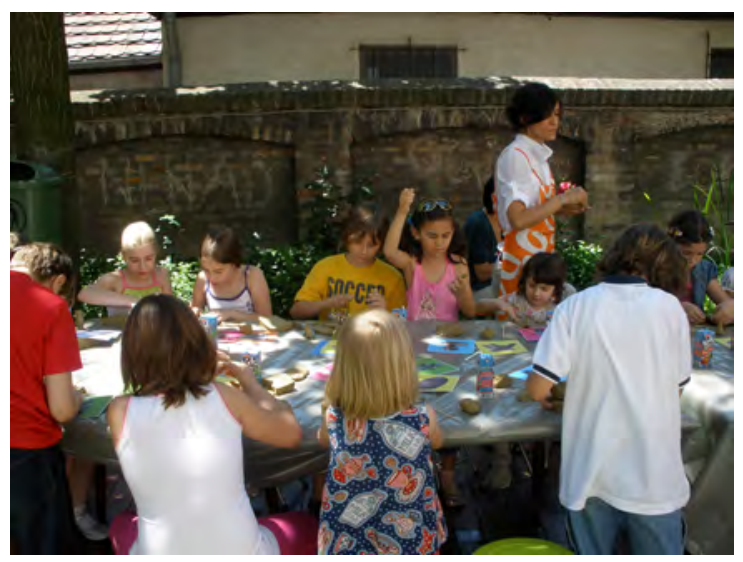

Fig. 2 Workshop Life in Clay

of modern education namely: fun, motivation and close contact with the subject. This involved an active and practical interpretation, which required that the teaching was directed to the participating children as an audience in an open manner. Museums should aim to create public interest in someone or something and they will thus cease to be isolated and remote institutions. (Popović 2011: 20). Solving tasks is a very important educational strategy for museums, so these institutions have to deal with these tasks systematically (Panić 2011: 31,32).

Consequently, the exchange of experience is extremely valuable and necessary in this field of work. For that reason the thematic seminars are relevant to gathering knowledge and its exchange, between experts from different fields of work such as art history, archeology, ethnology, biology, architecture, among others. Seminars on the methodology establish a standard which could be applied in workshops for children with differ-

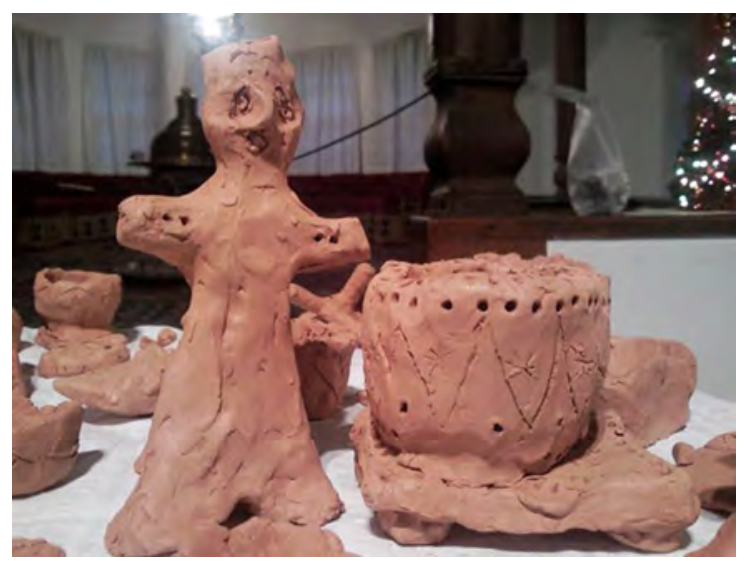

Fig. 4 Children's finished works: Figurine and altar 


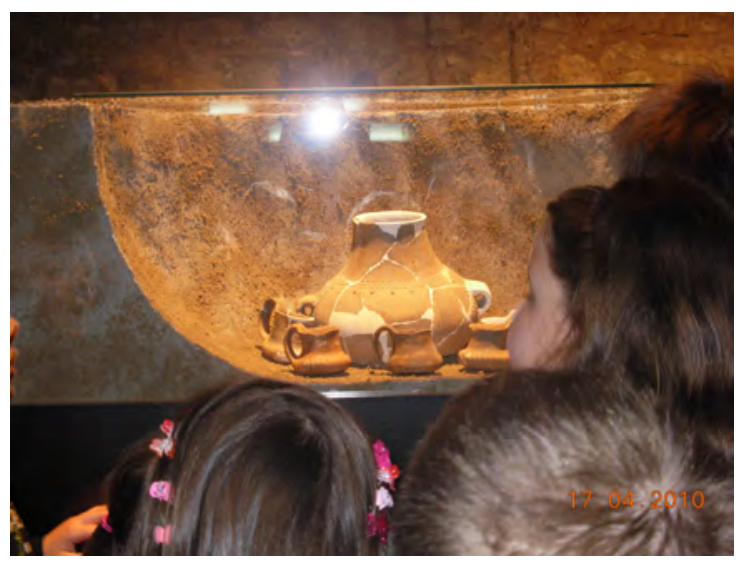

Fig. 5 Exhibition First toast

ent levels of prior knowledge, so they can easily and efficiently understood the unique aspects of heritage which is represented in permanent or temporary exhibitions (Čolak Antić 2011: 30). There are numerous examples about how such programs should be maintained within the museums. This will result in influencing our thinking as to the methods that are applied in the organization of permanent workshops inspired by archeology. This is how, initially, the participating children were introduced to the culture of various periods and their history, by providing explanations in keeping with age profiles (5 to 14) and the level of understanding of the children. The establishment of both the workshops and the exhibitions in the one location facilitated the interactive education and the successful imparting of knowledge on the chosen subject. The claim that learning, by its essential nature, is interactive was confirmed through the increasingly vibrant activities and participation by the many museums working with

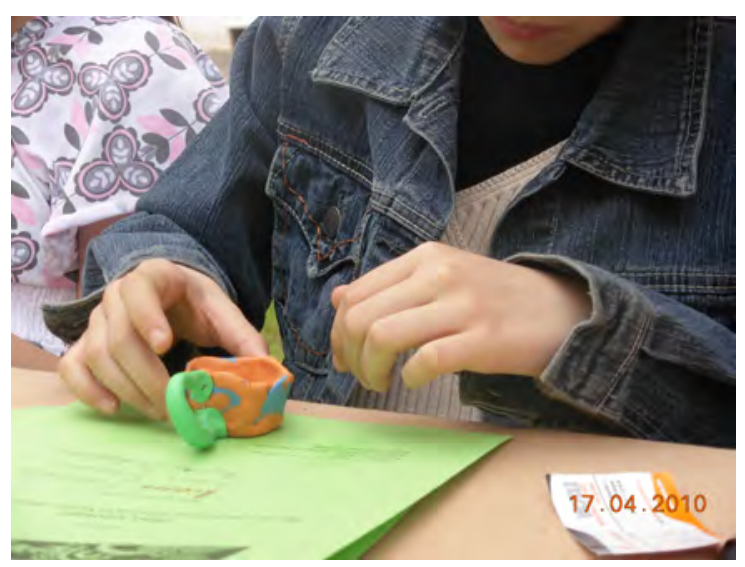

Fig. 7 Imitation of Baden cup

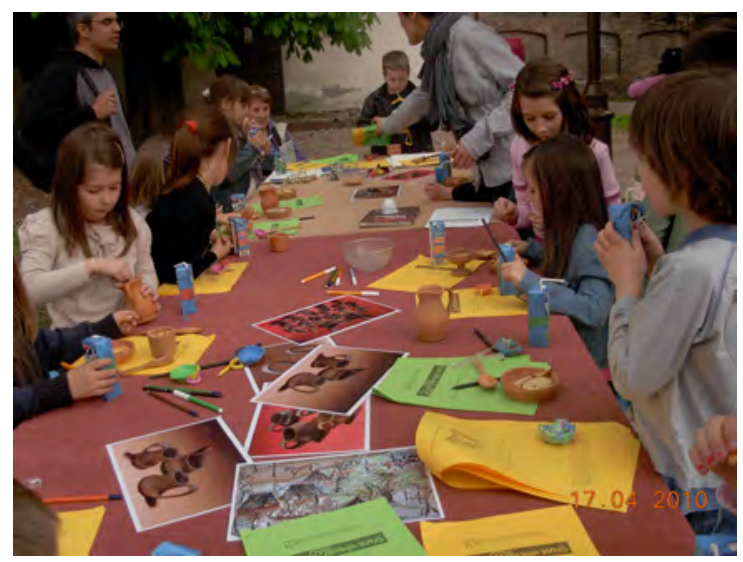

Fig. 6 Workshop First toast

children. Interaction here, in the broadest sense, is understood as the interaction with the physical environment, social environment and is the object of cognition. The creation of cognitive conflict is a very important educational mechanism, which is realising what the child already knows, recognizes, and can view as new knowledge (Павловић Лазаревић 2009: 132).

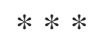

All of the archaeological exhibitions in the Museum included ceramic items and consequently, all the workshops included objects modeled in clay by the children who participated. During their creative work, the children were introduced to techniques and technologies of producing clay objects from the various periods chosen.

In 2009 during the first archaeological exhibition, a workshop was organized for children with the concept Life in clay (Петровић 2009).

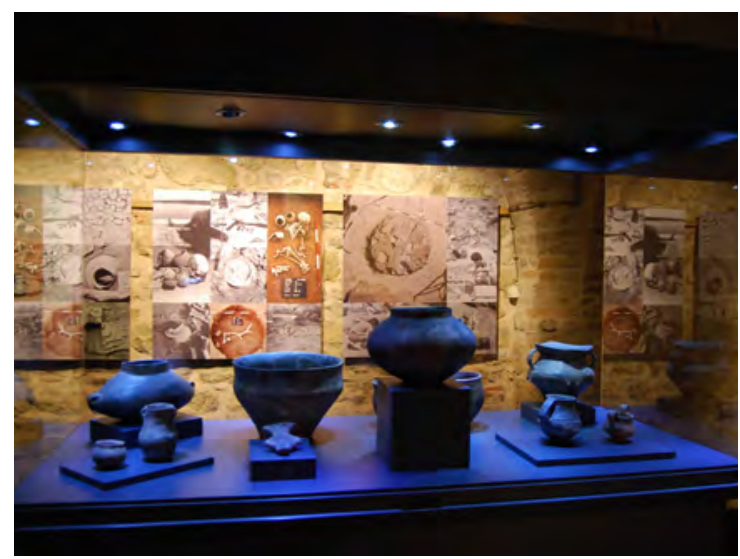

Fig. 8 Exhibition Vinča, Fragments for Reconstruction of the Past 


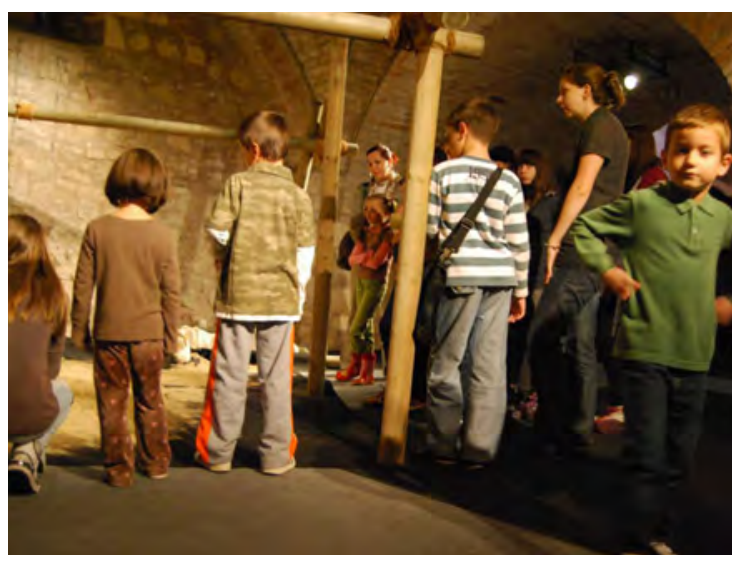

Fig. 9 Children introduce the exhibition content

The Exhibition presented prehistoric art about the Belgrade area and its surroundings from early to late Neolithic (сca 6200-4500 BC). Figural plastic art expressed in clay reflects the spirituality of the people of that time, as well as aspects of their everyday life.

Most of the items were cult objects and symbols of fertility: anthrophomorphic figurines (usually female, like presentations of Great Mother are), animal figurines (sheep, goat, pig, bull etc.), prosopomorphic lids (with presentation of human or animal face) and amulet pendants of various shapes (fig. 1).

All of these objects were very interesting for children. Simple shapes and incised ornamentation were suitable for modeling in clay, so children made various objects in Neolithic shapes, very successfully (fig. 2-4).

The next exhibition took place in early 2010 and was titled First Toast (Спасић 2010). The core of this exhibition was the group finds

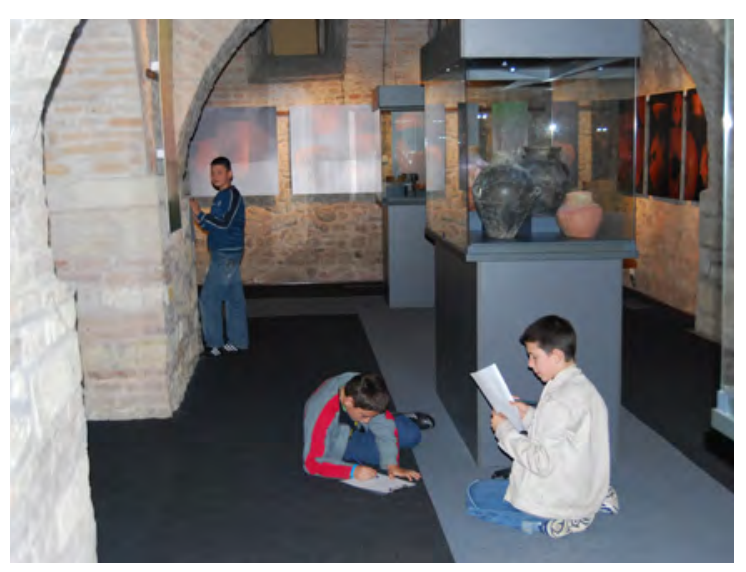

Fig. 11 Drowing exhibited items

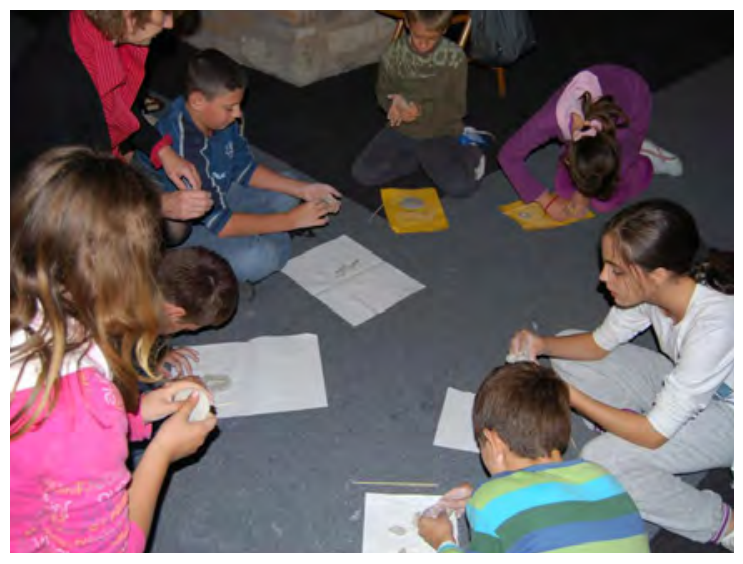

Fig. 10 Making objects in clay

of Baden cups from the Belgrade area from the late Eneolithic period (3600- 2600 BC). Most of the objects are from systematic archaeological investigations. Baden cups belong to the group for serving and consuming. Cups have a very simple shape and are small in size and were made by hand from one lump of clay. The strap was made separately and than joined to the rim. The shapes of these cups can be biconical, globular or cilindrical (fig. 5). The shapes are very similar to the shapes of some cups in use today.

In addition, objects similar to those presented in the Exhibition, were also modeled in plasteline by children in the younger age group attending the Workshop, because they were capable of making such simple shaped objects (fig. 6, 7).

The archaeological exhibition named Vinča, Fragments for Reconstruction of the Past, gave children an insight to the various objects of the Vinča period (Игњатовић 2010). This exhibition included ceramic objects found during a system-

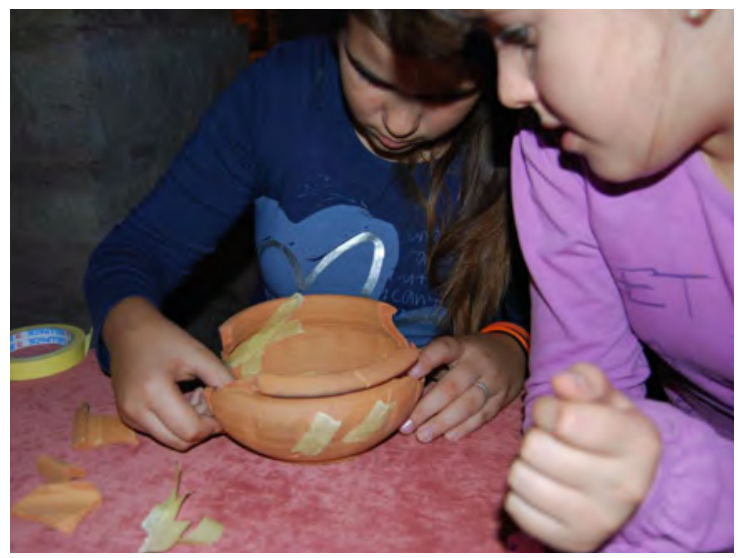

Fig. 12 Fixing pottery fragments 


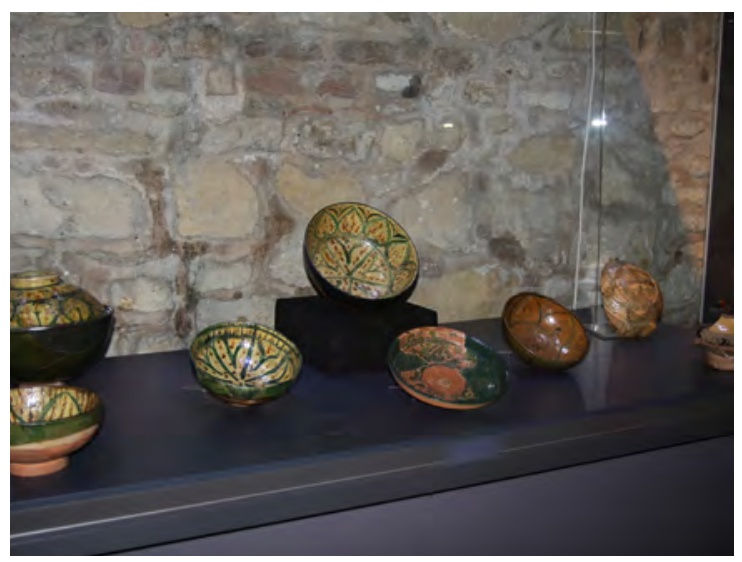

Fig. 13 Exhibition Painted Ceramics

atic exploration of archaeological site VinčaBelo Brdo, such as: vessels, altars and various objects of figural plastic art. The exhibition also included a presentation of the archaelological exploration and the conservation of the dig site in situ, as well as conservation of ceramic objects, and reconstructions of Neolithic settlement (fig. $8,9)$ Consequently, there was an intensive education program for children who were introduced to archaeological work and obtained knowledge about the Neolithic materials and culture in a very practical and picturesque fashion. This workshop also consists of work on modeling objects in clay, making drawings of the objects on exhibition and fixing contemporary pottery fragments (fig. 10-12).

The last exhibition also in 2010 was Painted Ceramics and involved restoration work, which was undertaken with the idea of gaining a more complete and clear insight into the local culture and heritage (Адамовић 2010). Painted vessels dating

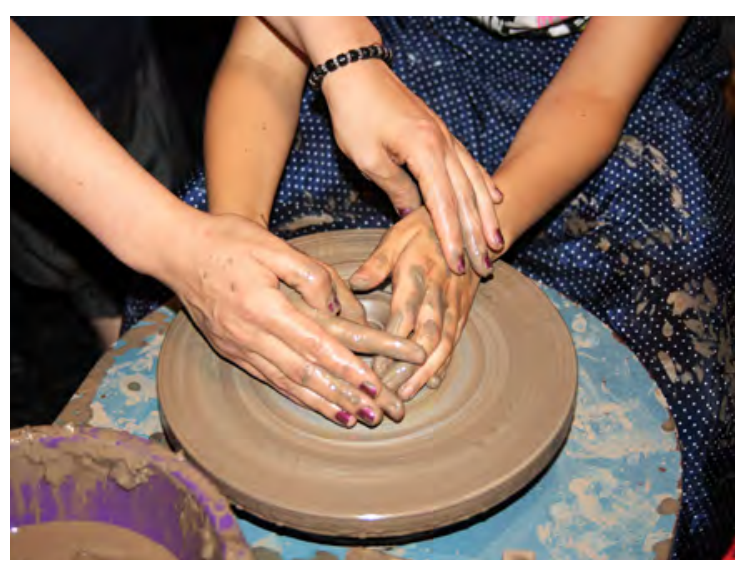

Fig. 15 Making ceramics by pottery wheel

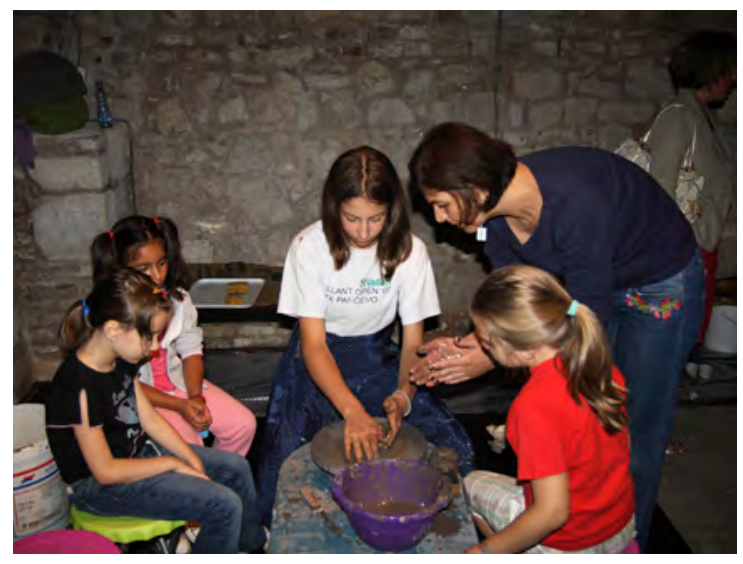

Fig. 14 Workshop Painted Ceramics

from various periods were presented from the Belgrade City Museum collection (from 15th to 18th century). The majority of these vessels represented excellent pieces of applied art. The presentation included luxurious pottery decorated by sgraffito and majolica techniques (fig. 13).

Workshops connected with this exhibition were extremely complex, as production technology for ceramics from this period is much more involved, as for example sgraffito technique was used. The most abundant remains of sgraffito pottery date from $15^{\text {th }}$ to $17^{\text {th }}$ centuries and originate from the Belgrade fortress, which were discovered

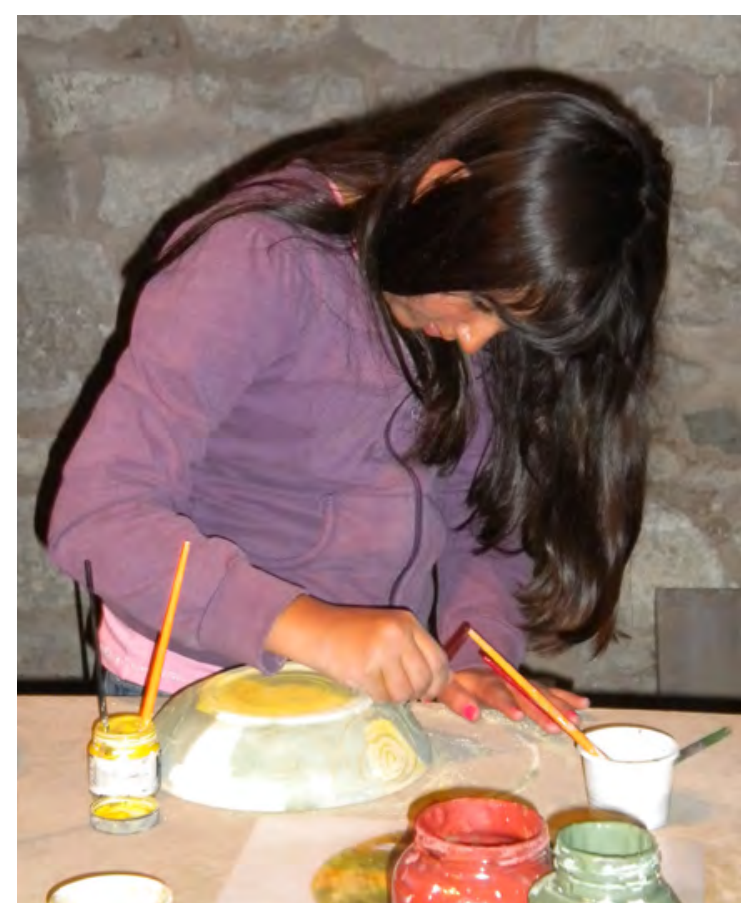

Fig. 16 Painting ceramics 


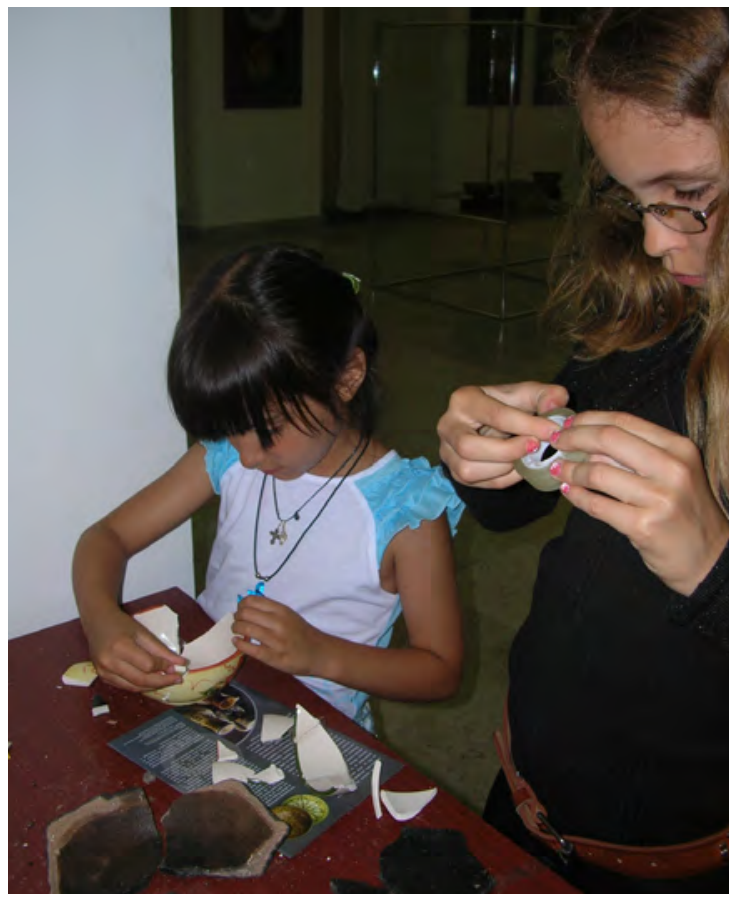

Fig. 17 Workshop in Herceg Novi

during systematic archeological investigations. This type of sgraffito ceramic, developed under Byzantine influence, were made by the fast pottery wheel. The distinguishing feature of this type of pottery is the combination of several decorating techniques, such as: incision, painting and glazing.

The children who attended this latter Workshop made plates and bowls using a pottery wheel and then decorated them in a similar manner to the original technique (fig. 14-16). All these activities were supervised by the experts. After completing the decoration, all items were glazed and fired, so that they could be put to practical use (fig. 28).

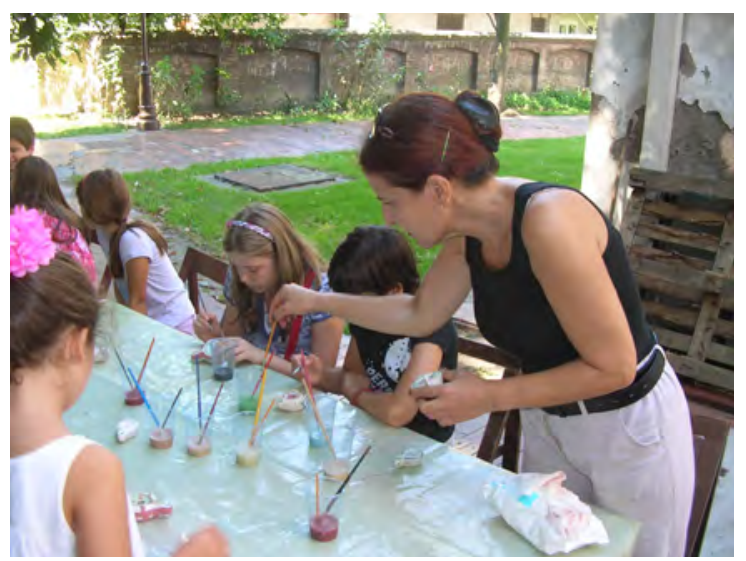

Fig. 19 Workshop Recte Illuminas

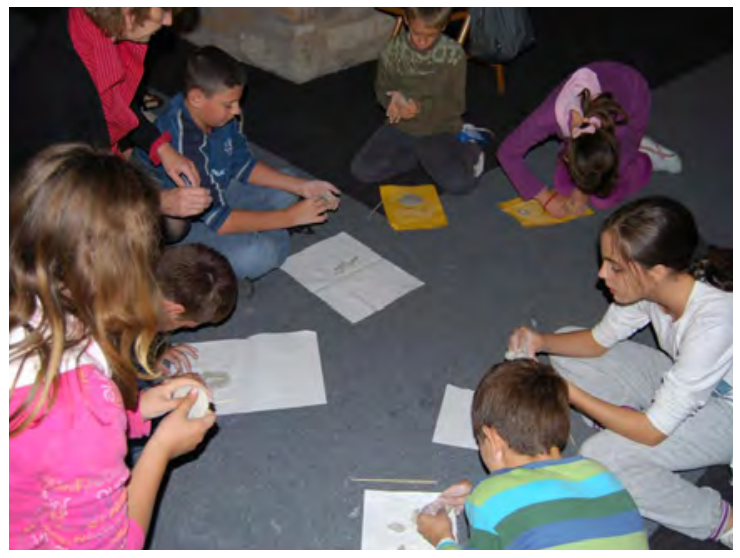

Fig. 18 Exhibition Recte Illuminas

The same exhibition was replicated in Herceg Novi - Montenegro 2011 (Adamović 2011). Due to budgetary constraints it was not possible to repeat this kind of more expensive workshop, so a more simple solution had to be found. Hence, contemporary ceramics were broken and exhibited, so that every visitor could try to fix the broken ceramics in conjunction with the restorator (fig. 17).

The last archaeological exhibition in the Belgrade City Museum took place in 2011 and was named Recte Illuminas, the exhibition of Roman lamps (Krunić 2011). The central part of the exhibition consisted of objects for illuminating: lamps, hanging lamps, candlesticks, lanterns etc (fig. 18). These objects had been used from the $1^{\text {st }}$ to the $5^{\text {th }}$ century and the most numerous were lamps of clay. The greatest number of lamps were discovered in Roman Singidunum by systematic archaeological exploration.

As this exhibition took place over a period of three months, there were several associated workshops. In the first workshop the children who

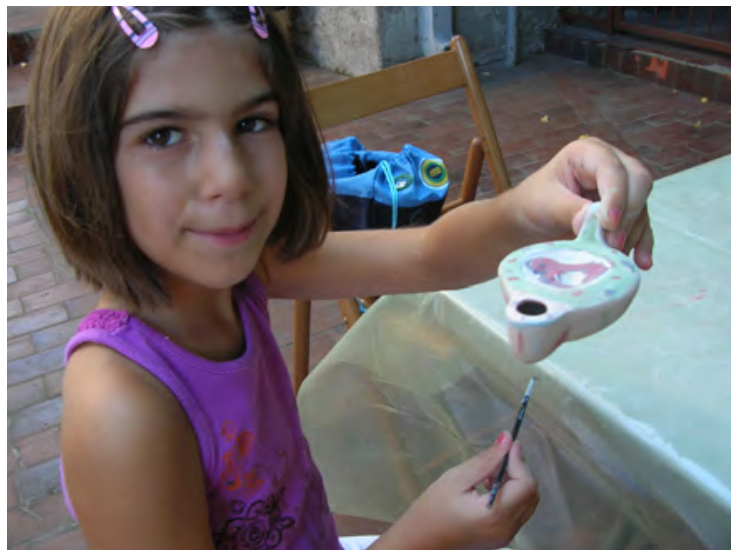

Fig. 20 Painting lamps 


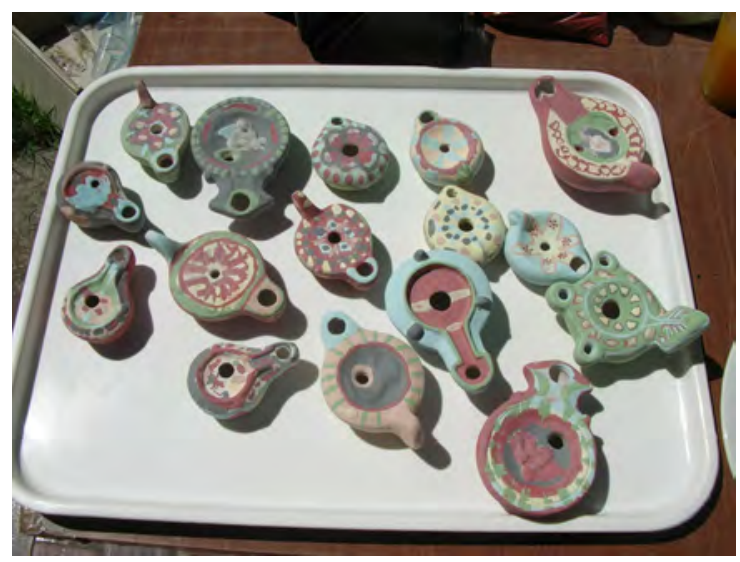

Fig. 21 Children's works before glazing and fireing

participated painted clay copies of Roman lamps. By making clay copies in a mould, those lamps with interesting shapes and decorations were chosen as models suitable for painting and emphasizing shapes: lamps with representations of animals on the disc as dolphin, lion, eagle, dog, bird, as well as some specimens with the portrait of historical person (fig. 19-21). Later, those lamps were glazed and fired and while they were very decorative, they were also ready for practical use (fig. 29).

In the next workshop candlesticks were made in clay by hand and also were painted (fig. 22). Children used their imaginations and made various shaped objects, sometimes inspired by Roman patterns. These objects were also glazed and fired.

Two further workshops promoted decorative art and used different materials, but were also based on the Roman period. The first organized workshop involved Roman glass. This involved a specific glass manufacturing technique known

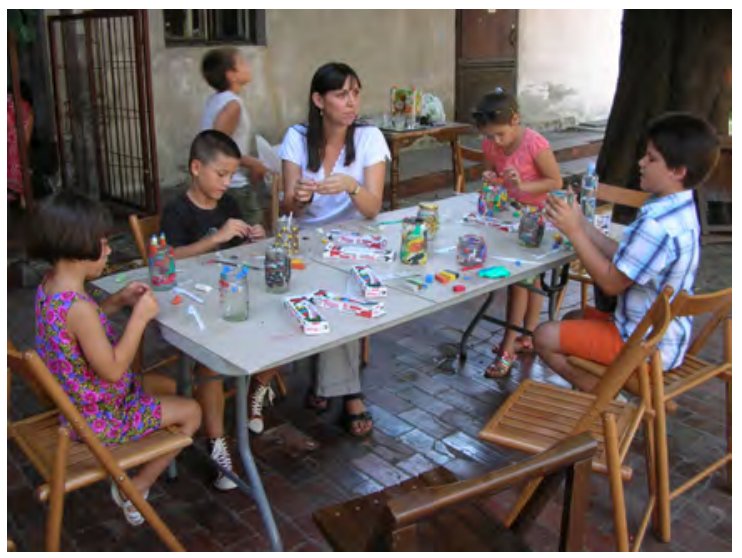

Fig. 23 Workshop Mille Fiori

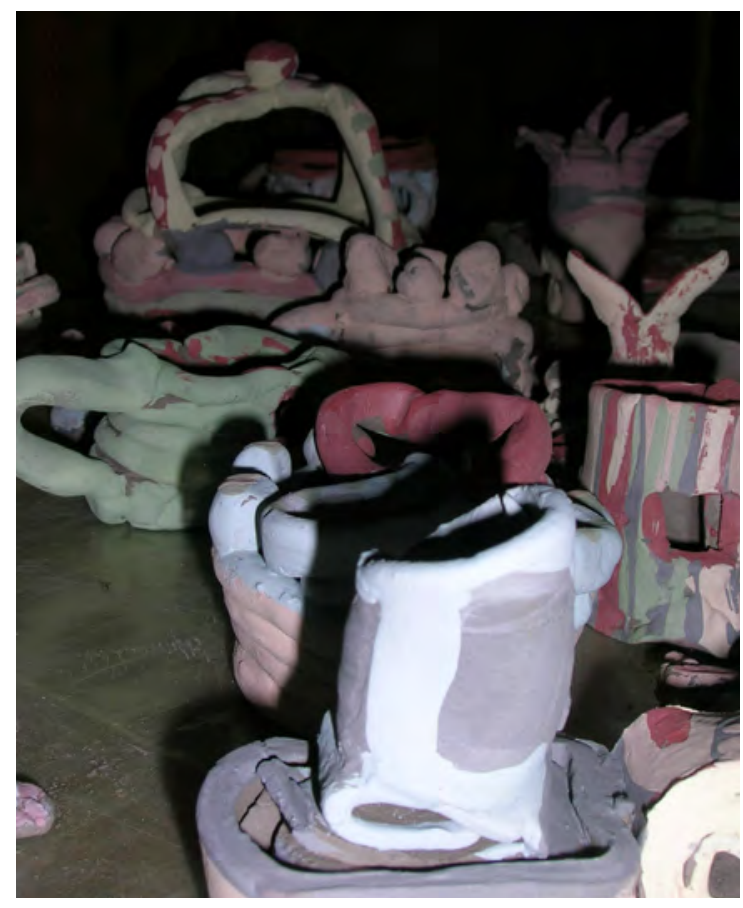

Fig. 22 Painted candlesticks

as Mille fiori, traced to Ancient Roman time. The technique was imitated by applying colored plasteline on contemporary glass (fig. 23, 24).

In the next workshop, the children were introduced to the technique used in the making of Roman mosaic ornaments. The imitations of Roman mosaic ornamentation were made by applying pieces of coloured paper (fig. 25, 26).

As a result of producing finished products, from the workshops: Painted Ceramics and Recte Illuminas, there stemmed the idea for an Exhibition and Sale of the children's finished work, which proved very constructive and intellectually rewarding for all participants (fig. 27-29).

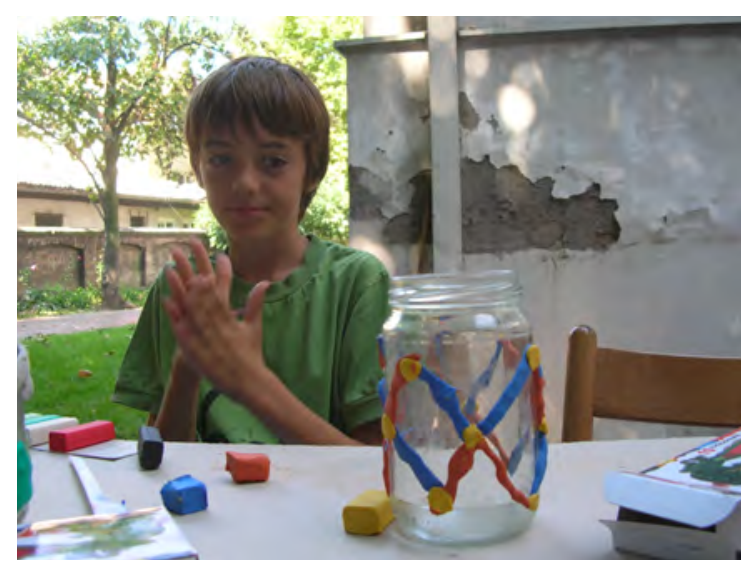

Fig. 24 Imitation of Mille Fiori technique 


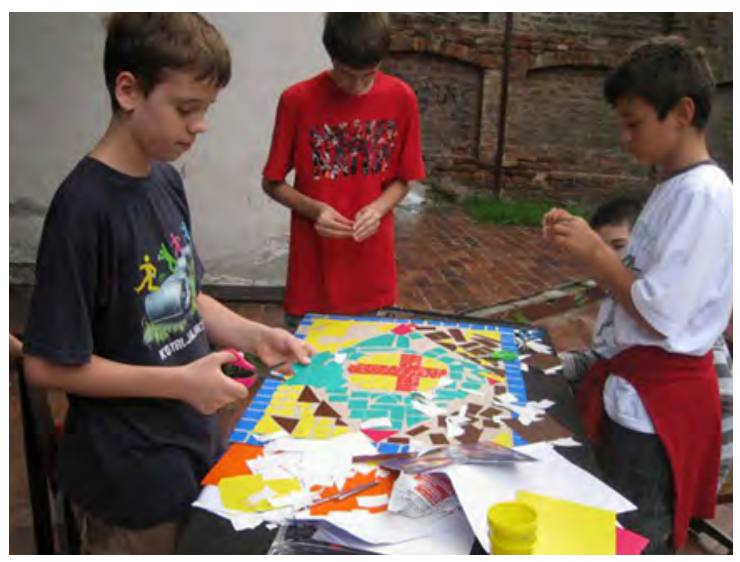

Fig. 25 Workshop Roman Mosaic

This was especially the case as the participating children in the Exhibitions were primarily chosen from the more deprived social and economic backgrounds and the realisation of the commercial value accruing to their work certainly improved their confidence and feeling of self worth.

$$
* * *
$$

During the preparation and implementation of the workshops for children in Belgrade City Museum, priority was given to ensure that the youngest participants found the content interesting followed by the creative work which was inspired by the original museum objects on exhibit during the current archaeological exhibitions.

Also, care was taken to avoid the imposition of strict data about items, and keep explanations simple and interesting. Primary aim was to encourage the children to experience the objects

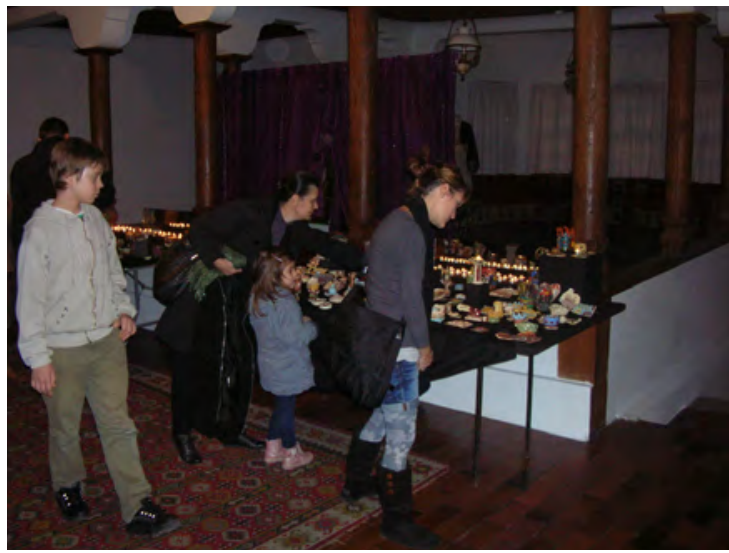

Fig. 27 Exhibition and Sale of children's works

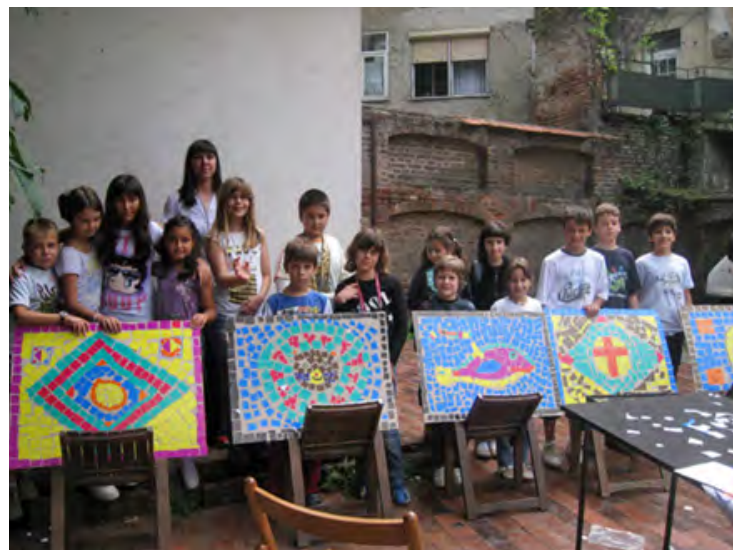

Fig. 26 Children's finished works

themselves, to think about them and reach a conclusion about their manufacture and use. In this way, their educational experience was something more than traditional learning.

The children made objects of clay almost independently, as a result of the archaeological finds, and were involved in all creative processes of making ceramics, where they made shapes of clay, followed by the various stages of drying, baking and painting, which proved to be an exhilarating method to introduce them to the museum items: their historical, artistic and applied content.

By participating in such workshops, the children were able to look at history from a different perspective and were encouraged to think critically, to discuss the importance of an active knowledge of their cultural heritage. These workshops proved to be extremely educational, entertaining and constructive for the children, as they were free to question all about the subject and in the same time to experience their artistic preferences.

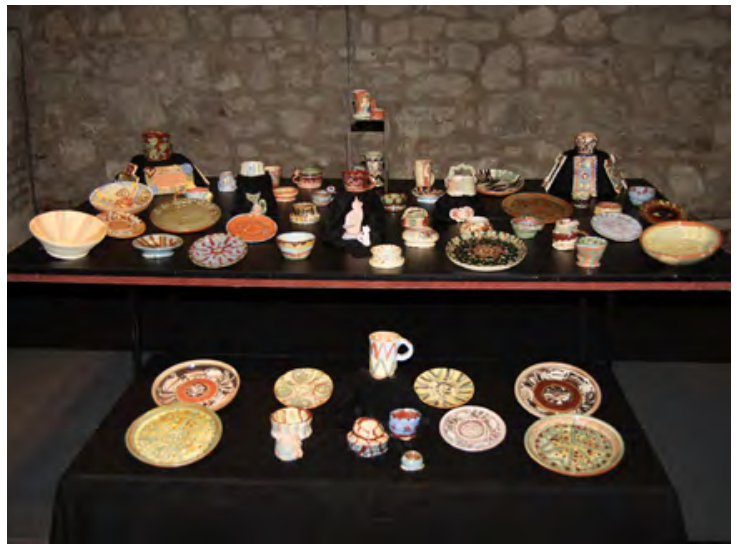

Fig. 28 Finished products from Workshop Painted Ceramics 


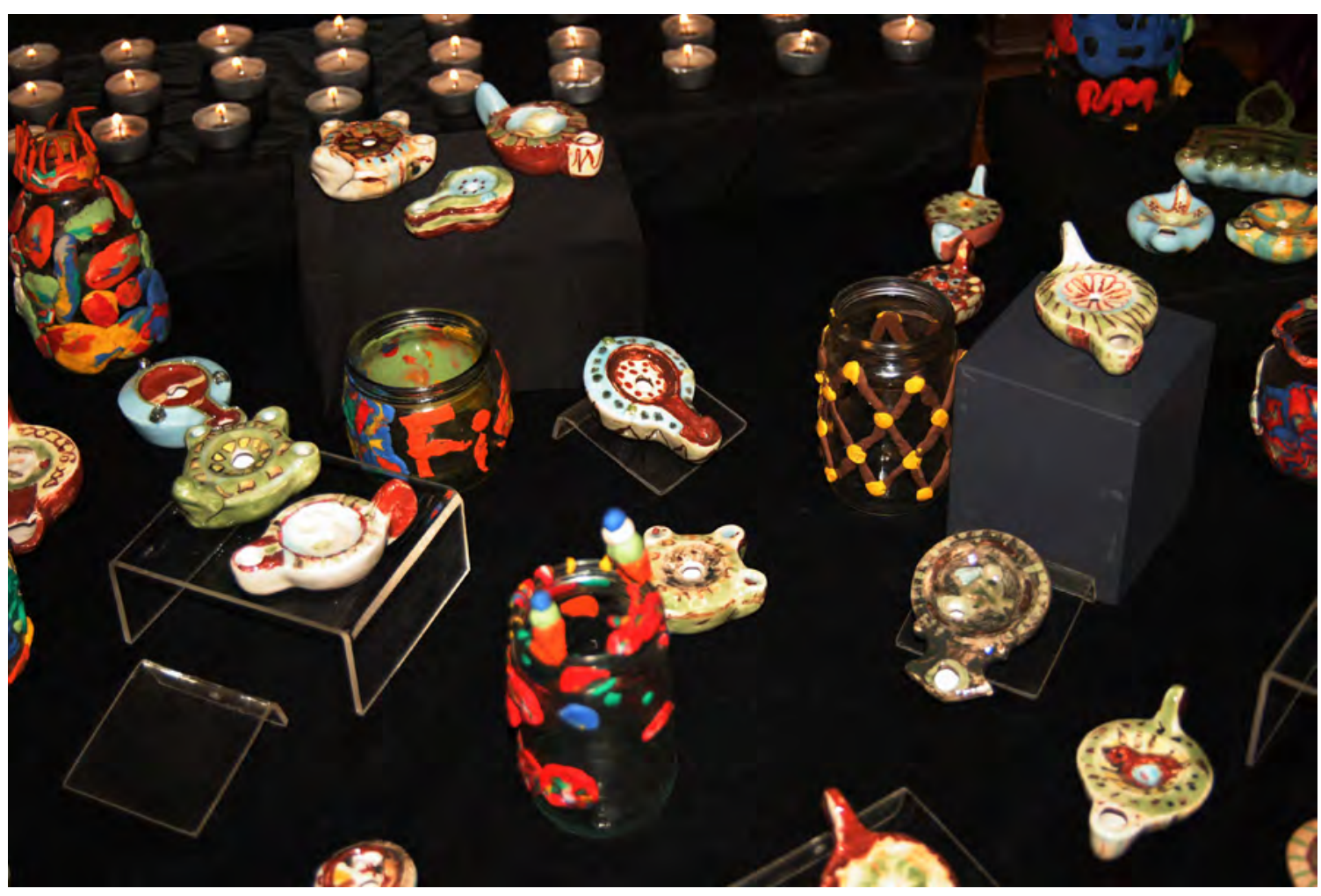

Fig. 29 Finished products from Workshop Recte Illuminas

It is our considered opinion that this exposure of the children to various aspects of their historic culture through the workshops is a most constructive way to educate our young citizens and provide them with an appreciation about the various aspects of their history and prepare a future museum visitors, as well as future archaeologists.

\section{BIBLIOGRAPHY}

Адамовић, Н. 2009

Рестаурација и реконструкција сликане керамике, Годишьак града Београда 55-56 (2008-2009): 89-113.

\section{Adamović, N. 2011}

Painted Ceramics from the Collections of the Belgrade City Museum, Exhibition leaflet, Belgrade: Belgrade City Museum.

\section{Čolak-Antić, T. 2011}

Seminar ,'Škola nasleđa", ICOM Srbija br.1 (2011): 30-31.
Игњатовић, М. и др. 2010

Винча, Фрагменти за реконструкиију прошлости, Каталог изложбе 58, Београд: Музеј града Београда.

\section{Krunić, S. 2011}

Recte Illuminas, Antique Lamps from Belgrade City Museum, Exhibition catalogue No 59, Belgrade: Belgrade City Museum.

\section{Павловић Лазаревић, Г. 2009}

Да ли могу опет да дођем? Едукативна радионица у Педагошком музеју, пројекат, Музеји бр.2 (н.с.) (2009): 121-163.

\section{Panić, A. 2011}

Umetnost bavljenja publikom, ICOM Srbija br.1 (2011): 31-34.

Петровић, Б., Катић, В. и Спасић, М. 2009 Живот у глини, Каталог изложбе 55, Београд: Музеј града Београда.

\section{Popović, U. 2011}

Istorijat edukacije, ukratko, ICOM Srbija br.1 (2011): 20-21. 
Спасић, М. 2010

Прва здравииа, Прича о баденскин шољама из Музеја града Београда, Каталог изложбе 56, Београд: Музеј града Београда.

\section{REZIME}

\section{KREATIVNE DEČIJE RADI- ONICE INSPIRISANE ARHE- OLOŠKIM IZLOŽBAMA U MUZEJU GRADA BEOGRADA}

Ključne reči: arheološke izložbe, Dečiji klub, edukacija, keramika, Muzej grada Beograda, radionice.

U Muzeju grada Beograda, od konstituisanja Dečijeg kluba 2004. godine, odvija se niz edukativnih i kreativnih programa, čiji je cilj, pre svega, popularizacija muzeja i upoznavanje mlađe generacije sa našim bogatim kulturnim nasleđem.

Za poslednjih pet godina realizovano je više dečijih radionica inspirisanih arheološkim izložbama, koje su pored kreativnog imale i edukativni koncept. Deca su upoznavana sa kulturnim i istorijskim periodima, odnosno muzejskim predmetima prezentovanim na aktuelnim izložbama, pri čemu se vodilo računa o njihovom uzrastu i mogućnostima pravilnog razumevanja.

$\mathrm{Na}$ svim arheološkim izložbama većinom su bili zastupljeni keramički predmeti, tako da su shodno tome sve radionice uključivale oblikovanje predmeta u glini, tokom kojeg su deca bila upoznavana sa tehnologijama izrade i tehnikama ornamentisanja keramičkih predmeta.

Tokom prve arheološke izložbe naslovljene Život u glini (izložba neolitske plastike), deca su oblikovala figurine i prosoporfne poklopce u glini, po ugledu na izložene. I tokom naredne izložbe Prva zdravica, na kojoj su prezentovane badenske šolje, deca su ponovo oblikovala predmete po ugledu na izložene.

Potom je otvorena izložba Vinča, Fragmenti za rekonstrukciju prošlosti, osmišljena kao prezentacija višegodišnjih istraživanja na lokakalitetu Vinča-Belo brdo, koja je uključivala i raznorodne keramičke predmete. Dečija radionica organizovana za tu priliku, bila je srodna predhodnim. 